\title{
How far is too far? An analysis of students' perceptions of the impact of distance between university and family home on academic performance
}

\author{
${ }^{1}$ ROSALINA PISCO COSTA \\ ${ }^{2}$ CARLOS VIEIRA \\ ${ }^{3}$ ISABEL VIEIRA \\ ${ }^{1}$ Universidade de Évora, CEPESE and CICS.NOVA.UÉvora \\ ${ }^{2}$ Universidade de Évora and CEFAGE (Centro de Estudos e Formação Avançada) \\ ${ }^{3}$ Universidade de Évora and CEFAGE (Centro de Estudos e Formação Avançada) \\ (C) 2017 Rosalina Pisco Costa, Carlos Vieira, Isabel Vieira \\ This is an open access article distributed under the Creative Commons Attribution-NonCommercial-NoDerivs license \\ (http://creativecommons.org/licenses/by-nc-nd/3.0/)
}

DOI: $10.1515 /$ eras-2017-0007

\begin{abstract}
Transition to university is a challenging phase in youngsters' lives. The literature indicates that geographical distance separating the places of study and of family residence adds to the difficulties of transition and adjustment to university. Recent evidence suggests that it also negatively impacts students' grades. Despite important work done by economists, geographers and psychologists, sociology has devoted scarce interest in understanding this topic. This article seeks to bridge this gap, specifically exploring the reasons justifying the largely ignored effect of distance between the university and family home in academic performance. The study draws on data on undergraduate students of a Portuguese public university, collected through an online survey. Two dimensions, one more related to practical life occupations and another more linked to personal feelings and activities, are examined. It is argued that the negative impact of distance is mainly due to homesickness and to the time spent traveling home. Results from such analysis are twofold socially relevant: of the utmost importance for families, academics and students' support services, deserve to be seriously considered by policy makers deciding on the territorial distribution of higher-education institutions.
\end{abstract}

Keywords: Academic performance, Geographical distance, Transition to university, Gender, Family

\section{INTRODUCTION}

Research suggests that geographically balanced higher-education systems have relevant positive impacts on individuals and societies (see, for instance, Tight, 1987 and 2007). At the personal level, institutional proximity limits the costs of attending higher education, enhancing choice and increasing participation, mainly for the less favoured in socioeconomic terms (Gibbons and Vignoles, 2012, and Cullinan et al., 2013). However, the effects of distance are not solely felt a priori, by those considering the continuation of studies. There is also evidence suggesting that distance separating the family home from the place of study may exacerbate some of the negative psychological (homesickness, depression), social (difficulties in adaptation to a new lifestyle or academic (dropout) problems experienced by students during transition to higher education (Chow and Healey, 2008).

In this study, the authors focus on the relatively less investigated impact of geography on academic performance and assess students' perceptions of the influence of distance separating family home and the place of study on their grades. Researchers from different areas of expertise have analysed higher-education students' experiences, examining issues such as persistence, attachment for the place of study, homesickness, or personal and socio- 
cultural determinants of adjustment to university. A brief review of such literature (provided in the next section) suggests that, even though the spatial dimension is not the main focus of attention, it is relevant for, and transversal to, most studied subjects. This justifies our attempt to add to current knowledge by exploring the students' perceptions of the effect of distance on their performance and attempting to distinguish between two dimensions (one more practical, another more personal) of such impact. Moreover, this topic seems particular interesting in South Europe countries, namely Portugal, usually characterized by a (still) strong family and gender tradition (Wall and Amâncio, 2007).

The article follows with an analysis of studies depicting the relevance of geography in the context of higher education, the presentation of the empirical investigation, the obtained results, main conclusions arising and respective implications.

\section{THE ROLE OF DISTANCE IN TRANSITION, ADJUSTMENT AND PERFORMANCE OF STUDENTS IN HIGHER EDUCATION}

Transition to university is a challenging phase in youngsters' lives and is distinctly perceived by all the parties involved (Ballantine \& Hammack, 2016). As referred by Chow and Healey (2008), whereas academics and families generally consider higher education a positive experience and a source of personal growth and enrichment, students face it with mixed feelings, simultaneously looking forward to and dreading what it involves. Entering university requires adjustment to a new way of life and to an unknown academic environment, with different pedagogical and learning approaches (Hurtado \& Carter, 1997; Hurtado et al., 2008). For many, it also involves geographical relocation, rendering higher-education students in general, and those in the first stages of their programmes, in particular, adequate subjects for researchers interested in investigating the many aspects of change and transition in late adolescence and young adulthood.

Environmental factors play a relevant role in adjustment to university and are more often a cause for failure to adapt than intellectual difficulties (Pitkethly and Prosser, 2001, Wilcox et al., 2005, Haarala-Muhonen et al., 2011). Therefore, even though the literature is rich in assessments of the students' learning processes and performance in higher education, many studies focus on other aspects. Tognoli (2003) mentions that the literature on transition could be roughly divided into studies assessing homesickness and studies focusing on adjustment (with or without homesickness involved). The former studies concentrate on relocated students who, for their age and voluntary displacement, are an interesting population for assessments of place attachment and homesickness.

Familiar places, such as the spaces we inhabit, are often objects of emotional attachment and sources of security and identity (see, inter alia, Tognoli, 2003, and Chow and Healy, 2008). For these reasons, dislocation from the family home may be stressful and disruptive (Dixon and Durrheim, 2004). Nonetheless, leaving home to attend university is a voluntary step that promotes independence and allows students to build the foundations for an independent adult life. Therefore, although the initial stages are challenging and unsettling, most students adapt and develop strong ties to their places of study (Chow and Healy, 2008).

Place attachment and place identity are indeed neither static nor exclusive. With time, people create grounding connections with multiple places and social environments (Lewicka, 2011). This dynamic process of adaptation is facilitated by place-referent continuity, i.e. by maintaining connections with places that are emotionally important (Twigger-Ross and Uzzell, 1996). Home, and its significant associations to family and old friends, play a pivotal role and facilitates the social exchange (Wiborg, 2004). Geography is thus relevant for attachment and identification with the place of study. Various studies suggest that, by 
allowing the possibility of frequent visits to the family and friends left behind, and providing a continuity that moderates the most traumatic aspects of leaving home; physical proximity enhances the gradual adjustment and stability of university students (Brown and Perkins, 1992; Chow and Healy, 2008; Xu et al., 2015). Attachment to the place of study also helps to reduce homesickness, one of the most widespread problems affecting relocated students (Scopelliti and Tiberio, 2010).

\section{EXPERIENCING HOMESICKNESS AT UNIVERSITY}

Homesickness at university is well documented across the globe - see, inter alia, Burt (1993) on Australia, Xu et al. (2015) on China, Tognoli (2003) on Italy, Stroebe et al. (2002) on The Netherlands, Brewin et al. (1989), Fisher et al. (1985) and Fisher et al. (1986) on England, or Carden and Feicht (1991) on Turkey and the United States. The literature suggests that homesickness is not gender specific, although women tend to seek social support more than men (Stroebe et al., 2002). It may be caused by changes in the students' routines, new social and intellectual challenges, or lack of parental physical proximity (Thurber and Walton, 2012). Homesickness is often associated to psychological perturbations (such as depression and anxiety), to cognitive failures and to difficulties in concentrating and handling academic work (Fisher and Hood, 1987), and is enhanced by the geographic distance separating the family home and the place of study (see, for instance, Fisher and Hood, 1987).

The association between homesickness and concentration problems, or with difficulties in coping with the academic tasks, could have prompted researchers investigating academic performance to consider physical distance from the family environment as a potential performance determinant. In fact, most results produced in the studies reviewed here suggest that there are various direct and indirect ways for distance to affect the students' performance. However, distance has mostly been ignored or laterally considered within this context. Exceptions are the studies developed by Luo et al. (2006), who showed that distance is detrimental for persistence, Katsikas and Panagiotidis (2011), examining long duration of studies in Greece using a dummy variable to differentiate students living with their families while attending university, and Vieira et al. (2017), who concluded that distance is a significant negative determinant of graduation grades, and thus that the impact of distance may prevail throughout the students' entire academic life, rather than solely during the first stages of transition.

In what follows, the authors add to the literature on academic performance by assessing the students' perceptions, and exploring two potential dimensions, of the influence of distance separating family home and place of study on their performance. Specifically, the analysis complements the relatively scarce set of studies investigating the impact of distance on some form of academic performance by providing a first attempt to explain how such effect occurs. From a micro scale point of view, these results have a considerable interest for families, academics and students' support services. Additionally, these data should also seriously be considered by policy makers deciding on the territorial distribution of highereducation institutions, therefore, contributing to strengthen other studies' remarks and conclusions sustaining the importance of developing new perspectives on the Portuguese higher education system (Pedrosa, 2017). 


\section{METHODOLOGICAL NOTE}

The study is supported by an extensive strategy of data collection within the universe of undergraduate students enrolled at a Portuguese public university - Universidade de Évora - in the academic year of 2014-15. The authors applied an on-line questionnaire entitled 'The influence of distance between university and family home on academic performance'. Data was collected using the Google ${ }^{\mathrm{TM}}$ platform, well known by students who frequently use it to read email messages, but also for its 'calendar', 'groups' or 'Hangouts ', functionalities. A pre-test was implemented with a few students from the target group, who suggested important changes in the wording of some questions, namely regarding the survey adaptation to the students' terminology when distinguishing between the family home and the place of residence during academic terms.

The study used an accidental sampling as the questionnaire was disseminated through the institutional mailing list of the first cycle students. This proved to be an important vehicle for establishing and evaluating the credibility of the online recruitment strategy in the absence of face-to-face interaction (Costa, 2017). In addition to the invitation to participate in the study, the introductory message asked students to share the questionnaire's link with their colleagues and also included a set of instructions, and ethical and deontological notes. The questionnaire was available online on GoogleDocs ${ }^{\dagger}$ for 15 days, from the $5^{\text {th }}$ to the $20^{\text {th }}$ of March 2015.

At the end, 1075 questionnaires were validated, corresponding to $24.3 \%$ of the population of active undergraduate students, including those in the first three years of integrated master programmes. The collected data was subsequently validated and analysed with univariate and bivariate descriptive statistical techniques, using IBM ${ }^{\circledR}$ SPSS ${ }^{\circledR}$ Statistics, version 21.

\subsection{PARTICIPANTS}

The Universidade de Évora's academic programmes are assigned to four Schools, reason why the respondents were grouped accordingly (Table 1). In the three years preceding data collection, females accounted for $55.7 \%$ of the university's new students. In this sample, they comprise $67.5 \%$ of respondents. In order to take the sample's female over representation into account, the data is analysed by gender.

Table 1: Population and sample

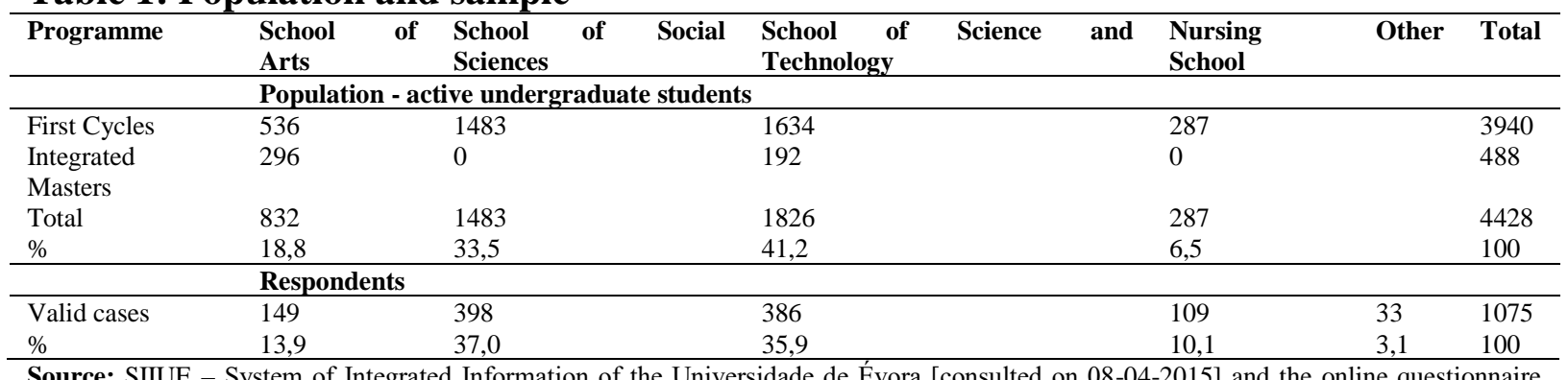

Source: SIIUE - System of Integrated Information of the Universidade de Évora [consulted on 08-04-2015] and the online questionnaire

*Since 2011, the Universidade de Évora's email service for students has been provided by Google Apps for Education. This service has the interface, space and quality of GMail yet maintaining the institutional email addresses in the format "username" @alunos.uevora.pt.

$\dagger$ The survey was available online at url: https://docs.google.com/forms/d/1alt6XyqKEYWwePL0BvkfZUnmaYJqSOn5yf5Oqx5AsI/viewform 
'The influence of distance between university and family home on academic performance' (applied in March/2015)

Note: Only 'regular' students were considered, i.e. external students and students in a mobility programme were excluded. For Integrated Master students, only those with fewer than 180 ECTS were accounted for. The option other comprises students whose programmes are not allocated to a single school.

Respondents are aged between 18 and 72 years ${ }^{+}$, with an average of 23.6 and a standard deviation of 6.6 years. $15.8 \%$ are working students (1073 valid cases). In terms of household composition (1071 valid cases), the majority $(65.2 \%)$ lives within a nuclear family, consisting of father and mother (or stepparent), with or without siblings; $16.3 \%$ live in single-parent families, with or without siblings; $8.3 \%$ live with a partner, with or without children; $10.1 \%$ live alone, in other domestic arrangements or in another, non-specified situation. $\S$

On average, the students in the sample entered the Universidade de Évora 2.6 years before the academic year of data collection (standard deviation is 2.1 and mode year is 2014), and expect to complete the first cycle program in 1.2 years (standard deviation is 1.2 and mode year is 2015).

In short, this sample mainly comprises undergraduates (more than half of which are females), mostly living in a nuclear family and attending the university as full time finalists, enrolled in programmes mainly assigned to the Schools of Social Sciences and Science and Technology.

\subsection{RELOCATED STUDENTS}

In Portugal, no university accommodation is available for students with families living within a commuting distance from the place of study. There is also no tradition of youngsters leaving home before completing an undergraduate program. Therefore, only students that did not live in the city of Évora (or its vicinity) before entering in higher education changed their place of residence to attend the Universidade de Évora. This is the case of the majority of the respondents in the sample. $70.2 \%$ (755 valid cases) are relocated from their families' place of residence during academic terms, whereas $29.8 \%$ (320 valid cases) did not have to move.

Table 2 depicts the living arrangements of relocated students and the characteristics of their visits in the family home. $74.9 \%$ live in rented accommodation (bedroom, apartment or house) and the rest is lodged at university halls of residences, in relatives' homes or in other, non-specified, conditions.

Table 2: Relocated students - accommodation and travels back home

\begin{tabular}{|c|c|c|c|c|c|c|c|}
\hline \multicolumn{8}{|c|}{ Accommodation (\% of 748 valid cases) } \\
\hline \multicolumn{2}{|c|}{ Rented accommodation } & $\begin{array}{l}\text { University } \\
\text { residences }\end{array}$ & \multicolumn{2}{|l|}{ Relatives' home } & \multicolumn{3}{|l|}{ Other } \\
\hline 74,9 & & 18,3 & 2,5 & & 4,3 & & \\
\hline \multicolumn{8}{|c|}{ Periodicity of returns to family home (\% of 750 valid cases) } \\
\hline Weekly & $\begin{array}{ll}\text { Every } & \text { other } \\
\text { week } & \\
\end{array}$ & Monthly & $\begin{array}{l}\text { Every } \\
\text { month }\end{array}$ & $\begin{array}{l}\text { Academic } \\
\text { breaks }\end{array}$ & $\begin{array}{l}\text { Summer } \\
\text { vacation }\end{array}$ & $\begin{array}{l}\text { End } \\
\text { programme }\end{array}$ & of \\
\hline 45,1 & 25,7 & 16,3 & 2,8 & 7,6 & 1,4 & 1,2 & \\
\hline \multicolumn{8}{|c|}{ Average duration of the round trip (\% of 750 valid cases) } \\
\hline \multirow{2}{*}{\multicolumn{2}{|c|}{$\begin{array}{l}\text { Up to } 2 \text { hours } \\
52,7\end{array}$}} & Half day & 1 day & & \multirow{2}{*}{\multicolumn{3}{|c|}{$\begin{array}{l}\text { More than } 1 \text { day } \\
28\end{array}$}} \\
\hline & & 37,9 & 6,5 & & & & \\
\hline
\end{tabular}

\$ Students with a "student-worker" status were also included in the sample.

${ }^{\S}$ It is possible that some respondents have considered that the question concerned their situation during academic terms, thus justifying an eventual over representation of those living alone (4.9\%). 
The majority of respondents left the family home to attend the Universidade de Évora and lives in rented accommodation in the city of Évora during academic terms. They mostly return home on weekends, or every other weekend, and spend up to two hours in each round trip.

\section{RESULTS}

One of the objectives of this research was to assess the students' perceptions about the influence of distance on academic performance. The survey included questions on this issue in three different moments, therein included with two purposes. Firstly, questions tried to grasp the students' general awareness of the influence of the distance on their academic performance. A direct question was included at the end of the questionnaire's first section (aimed at ascertaining the students' socio-demographic characteristics - moment 1) and asked again later, halfway through the questionnaire, before the questions designed to evaluate their involvement in a set of specific daily life activities (moment 2). Secondly, in the last part of the questionnaire, particular questions were included to collect information on their views on the influence of the distance on academic performance, not in general terms but in their personal cases (moment 3). The answers for these questions are reported in Table 3.

Table 3 - Impact of distance between university and family home on academic performance: gender $(\%)$

\begin{tabular}{|c|c|c|c|c|c|c|c|c|c|c|c|c|c|}
\hline & \multirow{3}{*}{ Impact on } & \multicolumn{4}{|c|}{ No impact } & \multicolumn{4}{|c|}{ Some impact } & \multicolumn{4}{|c|}{ High impact } \\
\hline & & & $\%$ & & & & $\%$ & & & & $\%$ & & \\
\hline & & VC & $\mathbf{T}$ & M & $\mathbf{F}$ & VC & $\mathbf{T}$ & M & $\mathbf{F}$ & VC & $\mathbf{T}$ & M & $\mathbf{F}$ \\
\hline Moment & Grades & 349 & 33,2 & 32,5 & 33,6 & 559 & 53,2 & 52,3 & 53,7 & 142 & 13,5 & 15,2 & 12,7 \\
\hline 1 & Time for programme completion* & 486 & 45,5 & 37,2 & 49,6 & 453 & 42,5 & 47,0 & 40,3 & 128 & 12,0 & 15,9 & 10,1 \\
\hline Moment & $\begin{array}{l}\text { Parental pressure for courses' } \\
\text { approval }\end{array}$ & 369 & 34,4 & 35,8 & 33,7 & 549 & 51,1 & 47,9 & 52,7 & 156 & 14,5 & 16,3 & 13,7 \\
\hline & Parental pressure for good grades & 405 & 37,7 & 40,4 & 36,5 & 550 & 51,3 & 48,4 & 52,6 & 118 & 11,0 & 11,2 & 10,9 \\
\hline $\begin{array}{l}\text { Moment } \\
3\end{array}$ & Own academic performance & 387 & 36,3 & 35,5 & 36,8 & 492 & 46,2 & 45,3 & 46,6 & 186 & 17,5 & 19,2 & 16,6 \\
\hline
\end{tabular}

Information in Table 3 suggests that students are aware of the impact of the distance on academic performance in the various perspectives considered. This is evident when evolving from a general perception (moments 1 and 2) to a self-perception about students' particular cases (moment 3). In fact, with the exception of the time needed to complete the programme, the sum of percentages for the categories 'some impact' and 'high impact' always adds up to more than $60 \%$ (reaching $66 \%$ in the cases of impact on grades and on parental pressure for courses' approval). Time to complete the programme registers the highest percentage of respondents considering it as non-affected by distance (45.5\%).

As the literature suggests (Stroebe et al., 2002), the students' perceptions of the influence of distance on academic performance are not, for the most part, gender dependent. In general, the answers of male and female respondents are not statistically different. The only dimension registering a statistically significant association with the respondent's gender is time needed to get a degree. In this case, female students consider the impact of distance as less important.

Concerning the perceptions about personal performance, although the gender differences are not statistically significant, a higher percentage of male students are aware of the adverse impact of distance, in line with Vieira et al. (2017), who concluded that the negative effect of distance on graduation grades is more relevant for them. The only items 
where females score higher in the sum of percentages for 'some impact' and 'high impact' are related to parental pressure, thus suggesting that males are somewhat less sensitive to it.

\begin{tabular}{|c|c|c|c|c|c|c|}
\hline \multirow[b]{2}{*}{ Impact on } & \multicolumn{2}{|l|}{ No impact } & \multicolumn{2}{|c|}{ Some impact } & \multicolumn{2}{|c|}{ High impact } \\
\hline & Relocated & Non relocated & Relocated & Non relocated & Relocated & Non relocated \\
\hline Grades & 32,6 & 34,8 & 54,5 & 50,3 & 12,9 & 14,9 \\
\hline Time for programme completion* & 48,4 & 38,8 & 40,4 & 47,3 & 11,2 & 13,9 \\
\hline Parental pressure for courses' approval & 34,5 & 34,1 & 50,4 & 52,8 & 15,1 & 13,1 \\
\hline Parental pressure for good grades & 38,1 & 36,9 & 49,8 & 54,7 & 12,1 & 8,4 \\
\hline Own academic performance $* *$ & 33,3 & 43,5 & 50,4 & 36,2 & 16,3 & 20,3 \\
\hline
\end{tabular}

Empirical data shows that relocation is more associated than gender with the respondents' perceptions regarding the impact of distance in different dimensions of their academic life (Table 4). There are statistically significant differences in the answers of relocated and non-relocated students in two of the five questions: time needed to complete the programme and own academic performance. The impact on grades registers the highest sum of percentages for some and high impact (67,4\% for relocated students).

After ascertaining awareness of the impact of distance on academic performance, both in general and in personal terms, the survey explored possible reasons to explain why it occurs. Accordingly, several questions were included in the form about the amount of time spent during academic terms in several dimensions of the daily life; some questions more related to practical domestic deeds, and others more linked to emotions and personal activities (Table 5). The justification for the choice of items is the attempt to distinguish between the two dimensions of the distance on the students' lives.

When leaving home to study, youngsters experience, often for the first time, the main responsibilities of independent life. They have to manage time and money, and may have to attend to basic needs (food, clean clothes, etc.) usually taken care of within the family context, perhaps with their collaboration, but most probably not under their responsibility. If living nearby, they may continue to count with the help of the family in some of such tasks (for instance, students who return home on weekends often do their laundry at home). But those visiting the family less often have to take care of their needs without help, thus having less time to devote to academic work. In contrast, relocation may relieve students from caring responsibilities such as looking after younger siblings, elderly family members, or helping in family businesses.

Aside from the more practical dimension, there are other aspects related to the family's absence and daily supervision that may interfere with the students' performance. They may feel homesick, or spend too much time online or going out, and thus being unable to achieve the adequate balance between academic duties and other personal or social activities. Table 5 reports results to questions on participation in activities and several dimensions of the daily life during academic terms.

Data shows that the majority of the activities and dimensions considered are not more time consuming during academic terms. The sum of percentages for lower and identical levels of participation is higher than $60 \%$ in all cases, except for the time spent traveling home $(50,8 \%)$ and felling homesick $(40,1 \%)$. The level of involvement in sports and cultural activities, taking care of dependents and relatives, and participating in online games and bets decreases for most respondents during academic terms. In contrast, homesickness and travelling home, and, to a lesser extent, shopping and other house chores, academic social life and cooking register a higher involvement of students. 
Table 5 - Participation in activities and dimensions of daily life during academic terms: gender $(\%)$

\begin{tabular}{|c|c|c|c|c|c|c|c|c|c|c|c|c|}
\hline \multirow[t]{2}{*}{ Activities/Dimensions } & \multicolumn{4}{|c|}{$\begin{array}{r}\text { Lower } \\
\%\end{array}$} & \multicolumn{4}{|c|}{ Same $\%$} & \multicolumn{4}{|c|}{$\begin{array}{r}\text { Higher } \\
\% \\
\end{array}$} \\
\hline & $\mathbf{V C}$ & $\mathbf{T}$ & M & $\mathbf{F}$ & $\mathbf{V C}$ & $\mathbf{T}$ & M & $\mathbf{F}$ & $\mathrm{VC}$ & $\mathbf{T}$ & M & $\mathbf{F}$ \\
\hline Cooking & 265 & 24.7 & 25,1 & 24,6 & 426 & 39.8 & 44,1 & 37,7 & 380 & 35.5 & 30,8 & 37,7 \\
\hline Laundry and ironing ${ }^{(1)}$ & 257 & 24.1 & 21,5 & 25,3 & 528 & 49.5 & 55,5 & 46,6 & 282 & 26.4 & 23,0 & 28,1 \\
\hline House cleaning & 230 & 21.5 & 23,3 & 20,6 & 539 & 50.3 & 51,6 & 49,7 & 302 & 28.2 & 25,1 & 29,7 \\
\hline Shopping and other house chores & 209 & 19.6 & 19,7 & 19,5 & 455 & 42.6 & 44,8 & 41,5 & 405 & 37.9 & 35,5 & 39,0 \\
\hline Caring for dependents ${ }^{(2)}$ & 512 & 48.3 & 41,9 & 51,3 & 479 & 45.1 & 49,6 & 43,1 & 70 & 6.6 & 8,5 & 5,7 \\
\hline Sports and cultural activities & 515 & 48.3 & 43,6 & 50,6 & 434 & 40.7 & 45,1 & 38,6 & 117 & 11.0 & 11,3 & 10,8 \\
\hline Travelling home ${ }^{(3)}$ & 192 & 18.0 & 20,3 & 16,9 & 350 & 32.8 & 36,2 & 31,1 & 526 & 49.3 & 43,5 & 52,0 \\
\hline Homesickness (missing family and friends) ${ }^{(4)}$ & 41 & 3.8 & 4,1 & 3,7 & 387 & 36.3 & 45,8 & 31,8 & 639 & 59.9 & 50,1 & 64,5 \\
\hline Academic social life (parties, meals, drinks, etc.) & 247 & 23.1 & 23,0 & 23,2 & 439 & 41.1 & 42,7 & 40,3 & 382 & 35.8 & 34,3 & 36,5 \\
\hline $\begin{array}{l}\text { Social networking (Facebook, Twitter, Instagram, } \\
\text { etc.) }{ }^{(5)}\end{array}$ & 166 & 15.5 & 21,0 & 12,9 & 700 & 65.5 & 63,1 & 66,6 & 203 & 19.0 & 15,9 & 20,5 \\
\hline On line games and bets ${ }^{(6)}$ & 433 & 41.7 & 31,8 & 46,5 & 564 & 54.3 & 62,6 & 50,2 & 42 & 4.0 & 5,6 & 3,3 \\
\hline Consumption of alcohol and/or drugs ${ }^{(7)}$ & 272 & 26.0 & 20,5 & 28,7 & 541 & 51.7 & 54,4 & 50,4 & 233 & 22.3 & 25,1 & 20,9 \\
\hline
\end{tabular}

Source: Online questionnaire 'The influence of distance between university and family home on academic performance' (applied in March/2015).

Notes: $\mathrm{VC}=$ valid cases; $\mathrm{T}=$ total; $\mathrm{M}=$ males; $\mathrm{F}=$ females; ${ }^{(1)} \chi^{2}=7,443, \mathrm{df}=2, \mathrm{Sig} .0,024 ;{ }^{(2)} \chi^{2}=9,098, \mathrm{df}=2, \mathrm{Sig} .0,011 ;{ }^{(3)} \chi^{2}=6,826, \mathrm{df}=2, \mathrm{Sig}$. 0,$033 ;{ }^{(4)} \chi^{2}=20,671, \mathrm{df}=2$, Sig. 0,$000 ;{ }^{(5)} \chi^{2}=13,148, \mathrm{df}=2$, Sig. 0,$001 ;{ }^{(6)} \chi^{2}=21,410, \mathrm{df}=2$, Sig. 0,$000 ;{ }^{(7)} \chi^{2}=8,567, \mathrm{df}=2, \mathrm{Sig} .0,014$

Participation in the various activities and dimensions of the daily life during academic terms is somewhat gender related. These data cannot be understood apart from major considerations on gender culture in Portugal, a country still characterized by the strong influence of traditional gender stereotypes and culture in the daily and organizational life (Wall \& Amâncio, 2007). In fact, significant associations were found between gender and seven of the twelve items considered: females spend more time than males on laundry and ironing, taking care of dependents, travelling home, feeling homesick and in social networking; whereas males spend more time than females on online gambles and bets, and consuming alcohol and/or drugs. Gender differences are not statistically significant for cooking, house cleaning, shopping and other house chores, sports and cultural activities, and academic social life. The fact that female students feel more homesick may justify their greater participation in social networking, and travelling home.

Table 6 - Participation in activities and dimensions of daily life during academic terms: relocated and non-relocated students $(\%)$

\begin{tabular}{|c|c|c|c|c|c|c|}
\hline Activities/Dimensions & $\begin{array}{l}\text { Lower } \\
\text { Relocated }\end{array}$ & $\begin{array}{l}\text { Non } \\
\text { relocated }\end{array}$ & $\begin{array}{l}\text { Same } \\
\text { Relocated }\end{array}$ & $\begin{array}{l}\text { Non } \\
\text { relocated }\end{array}$ & $\begin{array}{l}\text { Higher } \\
\text { Relocated }\end{array}$ & $\begin{array}{l}\text { Non } \\
\text { relocated }\end{array}$ \\
\hline Cooking $^{(1)}$ & 23,5 & 27,7 & 29,6 & 63,8 & 46,9 & 8,5 \\
\hline Laundry and ironing ${ }^{(2)}$ & 20,7 & 32,2 & 43,6 & 63,4 & 35,7 & 4,4 \\
\hline House cleaning ${ }^{(3)}$ & 17,7 & 30,5 & 44,8 & 63,5 & 37,6 & 6,0 \\
\hline Shopping and other house chores ${ }^{(4)}$ & 15,8 & 28,3 & 32,9 & 65,4 & 51,3 & 6,3 \\
\hline Caring for dependents ${ }^{(5)}$ & 54,2 & 34,2 & 38,5 & 60,8 & 7,2 & 5,1 \\
\hline Sports and cultural activities ${ }^{(6)}$ & 48,3 & 48,4 & 39,2 & 44,3 & 12,6 & 7,2 \\
\hline Travelling home ${ }^{(7)}$ & 17,1 & 20,1 & 28,8 & 42,1 & 54,1 & 37,7 \\
\hline Homesickness (missing family and friends) ${ }^{(8)}$ & 2,5 & 7,0 & 21,7 & 71,1 & 75,8 & 21,9 \\
\hline $\begin{array}{l}\text { Academic social life (going out for parties, meals, } \\
\text { drinks, etc. })^{(9)}\end{array}$ & 18,8 & 33,5 & 39,5 & 44,9 & 41,8 & 21,5 \\
\hline $\begin{array}{l}\text { Social networking (Facebook, Twitter, } \\
\text { Instagram, etc.) }{ }^{(10)}\end{array}$ & 12,1 & 23,5 & 65,9 & 64,6 & 22,0 & 11,9 \\
\hline On line games and bets ${ }^{(11)}$ & 42,2 & 40,5 & 52,9 & 57,6 & 4,9 & 1,9 \\
\hline Consumption of alcohol and/or drugs ${ }^{(12)}$ & 22,7 & 33,8 & 51,7 & 51,8 & 25,6 & 14,5 \\
\hline \multicolumn{7}{|c|}{ 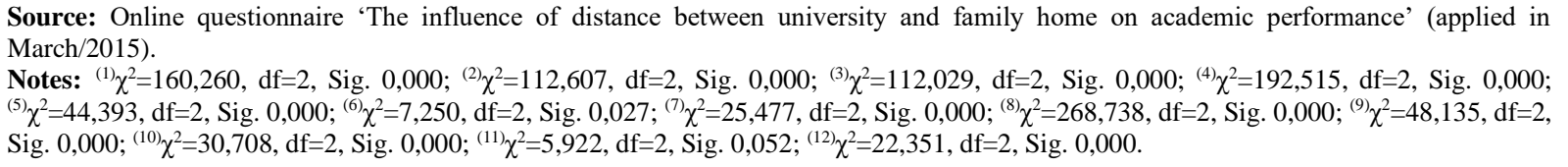 } \\
\hline
\end{tabular}

As expected, relocation from the family home is very relevant for students' involvement in the various activities and dimensions of the daily life during the academic 
terms. Significant associations with relocation were found for all activities and dimensions considered in the questionnaire (Table 6). Again, although the time spent by most relocated students in the considered activities and dimensions did not generally increase during academic terms, percentages higher than $40 \%$ for a higher involvement are registered for cooking, shopping and other house chores, travelling home, homesickness and academic social life.

Table 7 reports on the impact of the considered activities and dimensions on students' own academic performances. Overall, the majority of respondents consider that most activities have no impact on their performance. Only travelling home and homesickness register percentages below 50\% for 'no impact'. These two items have the highest percentage of respondents considering them as having a negative impact, whereas sports and cultural activities and academic social life have the highest percentages for positive impact. Unexpectedly, the effect of sports and cultural activities is not due to their contribution for students' physical and emotional wellbeing and thus, indirectly, to a better performance, but to the relative abandonment of such activities in higher education, and thus leaving more time available for study.

Table 7 - Impact of activities and dimensions of daily life on own academic performance: gender $(\%)$

\begin{tabular}{|c|c|c|c|c|c|c|c|c|c|c|c|c|}
\hline \multirow{2}{*}{$\begin{array}{l}\text { Impact } \\
\text { Activities/Dimensions }\end{array}$} & \multicolumn{4}{|c|}{$\begin{array}{r}\text { Negative } \\
\% \\
\end{array}$} & \multicolumn{4}{|c|}{ No impact } & \multicolumn{4}{|c|}{$\begin{array}{r}\text { Positive } \\
\% \\
\end{array}$} \\
\hline & $\mathrm{VC}$ & $\mathbf{T}$ & $\mathbf{M}$ & $\mathbf{F}$ & $\mathrm{VC}$ & $\mathbf{T}$ & $\mathbf{M}$ & $\mathbf{F}$ & $\mathrm{VC}$ & $\mathbf{T}$ & $\mathbf{M}$ & $\mathbf{F}$ \\
\hline Cooking $^{(1)}$ & 277 & 26.0 & 28,6 & 24,7 & 663 & 62.1 & 63,0 & 61,7 & 127 & 11.9 & 8,5 & 13,5 \\
\hline Laundry and ironing ${ }^{(2)}$ & 250 & 23.5 & 26,0 & 22,3 & 720 & 67.6 & 69,3 & 66,8 & 95 & 8.9 & 4,7 & 10,9 \\
\hline House cleaning ${ }^{(3)}$ & 264 & 24.8 & 25,1 & 24,7 & 669 & 62.8 & 67,6 & 60,5 & 132 & 12.4 & 7,3 & 14,8 \\
\hline Shopping and other house chores & 253 & 23.7 & 24,5 & 23,4 & 687 & 64.4 & 67,1 & 63,2 & 126 & 11.8 & 8,5 & 13,4 \\
\hline Caring for dependents & 249 & 23.4 & 26,8 & 21,8 & 700 & 65.9 & 64,4 & 66,5 & 114 & 10.7 & 8,7 & 11,7 \\
\hline Sports and cultural activities & 235 & 22.2 & 22,6 & 22,0 & 594 & 56.2 & 56,2 & 56,2 & 228 & 21.6 & 21,2 & 21,8 \\
\hline Travelling home & 582 & 54.6 & 50,6 & 56,6 & 425 & 39.9 & 43,8 & 38,1 & 58 & 5.4 & 5,6 & 5,4 \\
\hline Homesickness (missing family and friends) ${ }^{(4)}$ & 516 & 48.6 & 39,5 & 52,9 & 478 & 45.1 & 54,3 & 40,7 & 67 & 6.3 & 6,2 & 6,4 \\
\hline $\begin{array}{l}\text { Academic social life (going out for parties, meals, } \\
\text { drinks, etc.) }\end{array}$ & 297 & 28.0 & 32,0 & 26,1 & 575 & 54.1 & 52,8 & 54,8 & 190 & 17.9 & 15,2 & 19,1 \\
\hline $\begin{array}{l}\text { Social networking (Facebook, Twitter, Instagram, } \\
\text { etc.) }\end{array}$ & 278 & 26.2 & 26,1 & 26,3 & 689 & 65.0 & 64,8 & 65,1 & 93 & 8.8 & 9,1 & 8,6 \\
\hline On line games and bets & 271 & 26.1 & 26,9 & 25,6 & 749 & 72.0 & 70,1 & 72,9 & 20 & 1.9 & 3,0 & 1,4 \\
\hline Consumption of alcohol and/or drugs & 331 & 31.6 & 35,4 & 29,8 & 676 & 64.6 & 59,3 & 67,1 & 40 & 3.8 & 5,3 & 3,1 \\
\hline
\end{tabular}

There are statistically significant gender differences in five of the twelve items: cooking, laundry and ironing, house cleaning, homesickness and consumption of alcohol and/or drugs. In the first three cases, the positive impact is felt more by females and the negative impact more by males. The negative impacts of homesickness and of alcohol and/or drugs consumption are more relevant respectively for females and for males.

As expected, the impact of homesickness is higher for students who have started academic life more recently. While $52 \%$ of those entering the university in 2014 declared that homesickness has a negative effect on their academic performance, such percentage decreases to $47 \%$ for those entering before 2014 . 
Table 8 - Impact of activities and dimensions of daily life on own academic performance: relocated and non-relocated students (\%)

\begin{tabular}{|c|c|c|c|c|c|c|}
\hline \multirow{2}{*}{$\begin{array}{l}\text { Impact } \\
\text { Activities/Dimensions }\end{array}$} & \multicolumn{2}{|l|}{ Negative } & \multicolumn{2}{|l|}{ No impact } & \multicolumn{2}{|l|}{ Positive } \\
\hline & Relocated & Non relocated & Relocated & Non relocated & Relocated & Non relocated \\
\hline Cooking $^{(1)}$ & 28,3 & 20,4 & 57,9 & 72,0 & 13,8 & 7,5 \\
\hline Laundry and ironing (2) & 23,8 & 22,7 & 65,8 & 71,9 & 10,4 & 5,4 \\
\hline House cleaning ${ }^{(3)}$ & 25,4 & 23,3 & 60,3 & 68,8 & 14,3 & 7,9 \\
\hline Shopping and other house chores ${ }^{(4)}$ & 24,1 & 23,0 & 62,0 & 70,1 & 13,9 & 6,9 \\
\hline Caring for dependents & 22,3 & 26,1 & 67,1 & 62,9 & 10,6 & 11,0 \\
\hline Sports and cultural activities & 20,9 & 25,3 & 56,7 & 55,1 & 22,4 & 19,6 \\
\hline Travelling home ${ }^{(5)}$ & 59,9 & 42,1 & 34,4 & 52,8 & 5,6 & 5,1 \\
\hline $\begin{array}{l}\text { Homesickness (missing family and } \\
\text { friends) }{ }^{(6)}\end{array}$ & 58,0 & 26,6 & 35,0 & 68,7 & 7,0 & 4,7 \\
\hline $\begin{array}{l}\text { Academic social life (going out for } \\
\text { parties, meals, drinks, etc.) }\end{array}$ & 27,0 & 30,2 & 52,9 & 57,1 & 20,1 & 12,7 \\
\hline $\begin{array}{l}\text { Social networking (Facebook, Twitter, } \\
\text { Instagram, etc.) }\end{array}$ & 27,0 & 24,4 & 64,6 & 66,0 & 8,5 & 9,5 \\
\hline On line games and bets & 25,0 & 28,5 & 73,3 & 68,9 & 1,6 & 2,6 \\
\hline Consumption of alcohol and/or drugs & 31,6 & 31,6 & 65,0 & 63,6 & 3,4 & 4,8 \\
\hline
\end{tabular}

Relocation is, again, very relevant for the students' perceptions of the influence of the various activities and dimensions of the daily life on their own academic performance (Table 8). Although the majority of respondents consider that activities related to practical needs have no impact on their academic performance, such percentages are higher for the nonrelocated students.

The negative impact of travelling home and homesickness registers higher differences in the percentages for relocated and non-relocated students. Social networking, online games and bets, and consumption of alcohol and/or drugs register similar percentages in terms of impact, suggesting that the absence of family supervision makes no difference in this regard. The greater negative impact on the academic performance of relocated students is exerted by time spent travelling home and by homesickness.

\section{CONCLUSION}

Wondering "how far is too far?" this study developed an explanatory analysis of the influence of distance between the place of study and family residence on academic performance of undergraduate students. The objective was to assess perceptions of such influence and reasons justifying its impact. The answers to an online questionnaire indicate that students are aware of the impact of distance on the academic performance both in general terms and in their personal cases, and that relocated students are especially conscious of the distance's effect on their grades.

In order to ascertain possible reasons for the negative impact of distance, the questionnaire included questions about the students' involvement in a number of activities and dimensions of the everyday life during the academic terms, and their views regarding the impact of such activities on their own performance. The items were chosen to comprise two aspects of the students' lives: practical daily life tasks and personal feelings and activities. Most respondents do not feel that the considered activities and dimensions are more time consuming during academic terms, yet the levels of involvement of relocated and nonrelocated students are statistically significantly distinct. There is a higher involvement of relocated students in the more practical activities (e.g., cooking, shopping and other house chores), but also more time spent traveling home, feeling homesick and participating in the academic social life. Accordingly, more relocated students consider that such activities and 
dimensions have a negative impact on their performance. It is noteworthy that the highest percentages were registered for the time spent travelling home and feeling homesick.

It is interesting that no statistically significant differences between relocated and nonrelocated students emerged for the following activities: caring for dependents, social networking, online games and bets and consumption of alcohol and/or drugs. In the three last cases, although more than $25 \%$ of respondents consider that such activities have a negative impact on their academic performance, distance, and thus the absence of more intense family supervision appears to be irrelevant.

The results from this study come to show that the distance's negative influence on academic performance is mainly structured in two dimensions, reflecting both its manifest and latent implications in the students' lives: the time spent travelling home and homesickness. Although perceptions about the influence of distance are generally not gender related, female students appear to be more affected by homesickness, or at least more willing to admit it. The data also suggest that homesickness is more relevant for the first-year students, who did not yet have time to build new strong friendships in the academic environment.

Of the foregoing, this paper underlines the conclusion that the impact of distance between university and family home on academic performance is not just an academic or personal issue, rather cultural. In fact, either at a global or local scale, variables such as the impact of gender or homesickness have to be understood in the light of the cultural characteristics that distinguish countries and regions of studying and belonging. Particularly in Portugal, norms and values around family ties and gender roles cannot be neglected in this analysis. At the same time, more research needs to be done in the future, especially through semi-structured interviews, allowing for and in-depth analysis in the understanding of the influence of such variables and, eventually, unveiling new ones.

The results from this research also come to highlight the importance of a strategic thinking within the context of higher education at both the institutional and national levels. Firstly, these conclusions justify investing in broad and efficient student support services, specifically targeting relocated students, and especially those who, being first-year students, have recently left the family environment to attend university. Secondly, the results underline the importance of establishing, or maintaining a geographically equilibrated network of higher-education institutions, allowing equitable access without requiring undesired displacement from home.

\section{ACKNOWLEDGMENTS}

The authors acknowledge financial support from Fundação para a Ciência e a Tecnologia (grant UID/ECO/04007/2013) and FEDER/COMPETE (POCI-01-0145-FEDER-007659).The authors are also grateful to all those who kindly gave comments and valuable feedback on earlier versions of this paper. An exploratory work, presented as an oral communication in the III International Conference Learning and Teaching in Higher Education, held at the University of Évora (Portugal), April 15-17, 2015, was later published in Portuguese in the corresponding Proceedings. 


\section{REFERENCES:}

Ballantine, J. and Hammack, F. M. (2016). The Sociology of Education: A systematic Analysis. New York: Routledge.

Brewin, C., Furnham, A. and Howes, M. (1989). Demographic and psychological determinants of homesickness and confiding among students. British Journal of Psychology 80(4), 467-477. DOI: 10.1111/j.20448295.1989.tb02336.x

Brown, B. and Perkins, D. (1992). Disruptions in place attachment, in I. Altman and S. Low (Eds.). Place Attachment (279-304). New York: Plenum.

Burt, C. (1993). Concentration and academic ability following transition to university: an investigation of the effects of homesickness. Journal of Environmental Psychology 13(4), 333-342. DOI: 10.1016/S02724944(05)80255-5

Carden, A. and Feicht, R. (1991). Homesickness among American and Turkish college students. Journal of Cross-Cultural Psychology22(3), 418-428. DOI: 10.1177/0022022191223007

Chow, K. and Healey, M. (2008). Place attachment and place identity: first year undergraduates making the transition from home to university. Journal of Environmental Psychology 28(4), 362-372. DOI: 10.1016/j.jenvp.2008.02.011

Costa, R. (2017). Knockin' on digital doors. Dealing with online [dis]credit in an era of digital scientific inquiry, in M. Folk and S. Apostel (Eds.). Establishing and Evaluating Digital Ethos and Online Credibility (4665). Hershey: IGI Global. DOI: 10.4018/978-1-5225-1072-7.ch003

Cullinan, J., Flannery, D., Walsh, S., McCoy, S. (2013). Distance Effects, Social Class and the Decision to Participate in Higher Education in Ireland. The Economic and Social Review, 44(1), 19-51.

Dixon, J. and Durrheim, K. (2004). Dislocating identity: desegregation and the transformation of place. Journal of Environmental Psychology 24(4), 455-473. DOI: 10.1016/j.jenvp.2004.09.004

Fisher, S. and Hood, B. (1987). The stress of the transition to university: a longitudinal study of psychological disturbance, absent-mindedness and vulnerability to homesickness. British Journal of Psychology 78(4), 425-441. DOI: 10.1111/j.2044-8295.1987.tb02260.x

Fisher, S., Frazer, N. and Murray, K. (1986). Homesickness and health in boarding school children. Journal of Environmental Psychology 6(1), 35-47. DOI: 10.1016/S0272-4944(86)80033-0

Fisher, S., Murray, K. and Frazer, N. (1985). Homesickness, health and efficiency in first year students. Journal of Environmental Psychology5(2), 181-195. DOI: 10.1016/S0272-4944(85)80016-5

Gibbons, S. \& Vignoles, A. (2012). Geography, choice and participation in higher education in England. Regional Science and Urban Economics, 42(1-2), 98-113. DOI: 10.1016/j.regsciurbeco.2011.07.004

Haarala-Muhonen, A., Ruohoniemi, M. and Lindblom-Ylänne, S. (2011). Factors affecting the study pace of first-year law students: in search of study counselling tools. Studies in Higher Education 36(8), 911922. DOI: $10.1080 / 03075079.2010 .488722$

Hurtado, S. and Carter, D. F. (1997). Effects of College Transition and Perceptions of the Campus Racial Climate on Latino College Students' Sense of Belonging. Sociology of Education 70(4), 324-345. DOI: $10.2307 / 2673270$

Hurtado, S.; Griffin, K. A.; Arellano, L.; \& Cuellar, M. (2008). Assessing the Value of Climate Assessments: Progress and Future Directions. Journal of Diversity in Higher Education 1(4), 204-221. DOI: 10.1037/a0014009

Katsikas, E. and Panagiotidis, T. (2011). Student status and academic performance: accounting for the symptom of long duration of studies in Greece. Studies in Educational Evaluation 37(2-3), 152-161. DOI: 10.1016/j.stueduc.2011.03.009

Lewicka, M. (2011). Place attachment: how far have we come in the last 40 years?. Journal of Environmental Psychology 31(3), 207-230. DOI: 10.1016/j.jenvp.2010.10.001

Luo, M., Vieweg, B. and Schreck, C. (2006). Understanding the effect of student geographic characteristics on first-year persistence at a micropolitan university. Emporia: Emporia State University.

Pedrosa, J. (Coord.) (2017). Educação Superior em Portugal. Uma Nova Perspetiva. Lisboa: Fundação Calouste Gulbenkian.

Pitkethly, A. and Prosser, M. (2001). The first year experience project: a model for university-wide change. Higher Education Research and Development 20(2), 185-191. DOI: 10.1080/758483470

Scopelliti, M. and Tiberio, L. (2010). Homesickness in university students: the role of multiple place attachment. Environment and Behavior 42(3), 335-350. DOI: 10.1177/0013916510361872

Stroebe, M., Van Vliet, T., Hewstone, M. and Willis, H. (2002). Homesickness among students in two cultures: antecedents and consequences. British Journal of Psychology 93(2), 147-168. DOI: 10.1348/000712602162508

Thurber, C. and Walton, E. (2012). Homesickness and adjustment in university students. Journal of American 
College Health 60(5), 415-419. DOI: 10.1080/07448481.2012.673520

Tight, M. (1987). The location of higher education. Higher Education Quarterly 41(2), 162-183. DOI: 10.1111/j.1468-2273.1987.tb01774.x

Tight, M. (2007). The re(location) of higher education in England (revisited). Higher Education Quarterly 61(3), 250-265. DOI: 10.1111/j.1468-2273.2007.00354.x

Tognoli, J. (2003). Leaving home: homesickness, place attachment, and transition among residential college students. Journal of College Student Psychotherapy 18(1), 35-48. DOI: 10.1300/J035v18n01_04

Twigger-Ross, C. and Uzzell, D. (1996). Place and identity processes. Journal of Environmental Psychology 16(3), 205-220. DOI: 10.1006/jevp.1996.0017

Vieira, C., Vieira, I. and Raposo, L. (2017). Distance and academic performance in higher education. Spatial Economic Analysis. Published online: 29 Sep 2017. DOI: 10.1080/17421772.2017.1369146

Wall, K. and Amâncio, L. (2007). Família e Género em Portugal e na Europa. Imprensa de Ciências Sociais, Lisboa, Portugal.

Wiborg, A. (2004). Place, nature and migration: students' attachment to their rural home places. Sociologia Ruralis 44(4), 416-432. DOI: 10.1111/j.1467-9523.2004.00284.x

Wilcox, P., Winn, S. and Fyvie-Gauld, M. (2005). 'It was nothing to do with the university, it was just the people': the role of social support in the first-year experience of higher education. Studies in Higher Education 30(6), 707-722. DOI: 10.1080/03075070500340036

Xu, M., Bakker, M., Strijker, D. and Wu, H. (2015). Effects of distance from home to campus on undergraduate place attachment and university experience in China. Journal of Environmental Psychology 43, 95-104. DOI: 10.1016/j.jenvp.2015.05.013 